\title{
The Impact of Modern Technology Towards Malay Traditional Foods Preparation and Cooking Processes in Malaysia
}

Suhailah Abdul Ghafar Rahman, Farah Adibah Che Ishak, Mohd Mursyid Arshad, Mohd. Shazali Md. Sharif, Shahrim Ab Karim

To Link this Article: http://dx.doi.org/10.6007/IJARBSS/v11-i16/11230 DOI:10.6007/IJARBSS/v11-i16/11230

Received: 05 July 2021, Revised: 07 August 2021, Accepted: 25 August 2021

Published Online: 24 September 2021

In-Text Citation: (Rahman et al., 2021)

To Cite this Article: Rahman, S. A. G., Ishak, F. A. C., Arshad, M. M., Sharif, M. S. M., \& Karim, S. A. (2021). The Impact of Modern Technology Towards Malay Traditional Foods Preparation and Cooking Processes in Malaysia. International Journal of Academic Research in Business and Social Sciences, 11(16), 219-231.

Copyright: (C) 2021 The Author(s)

Published by Human Resource Management Academic Research Society (www.hrmars.com)

This article is published under the Creative Commons Attribution (CC BY 4.0) license. Anyone may reproduce, distribute, translate and create derivative works of this article (for both commercial and non-commercial purposes), subject to full attribution to the original publication and authors. The full terms of this license may be seen at: http://creativecommons.org/licences/by/4.0/legalcode

Special Issue Title: Contemporary Issues in Tourism and Hospitality industry, 2021, Pg. 219 - 231

Full Terms \& Conditions of access and use can be found at http://hrmars.com/index.php/pages/detail/publication-ethics 


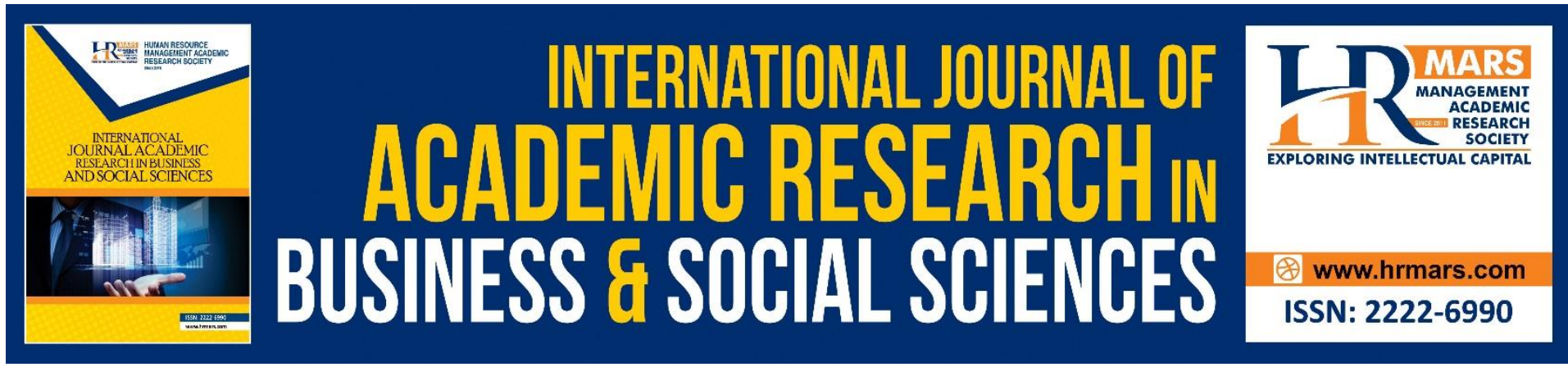

\title{
The Impact of Modern Technology Towards Malay Traditional Foods Preparation and Cooking Processes in Malaysia
}

\author{
Suhailah Abdul Ghafar Rahman ${ }^{1,2}$, Farah Adibah Che Ishak ${ }^{2}$, \\ Mohd Mursyid Arshad ${ }^{3}$, Mohd. Shazali Md. Sharif, Shahrim Ab \\ Karim ${ }^{2}$ \\ ${ }^{1}$ Faculty of Technical and Vocational, Universiti Tun Hussein Onn, 86400 Batu Pahat, Johor, \\ Malaysia, ${ }^{2}$ Faculty of Food Science and Technology, Universiti Putra Malaysia, 43400 UPM \\ Serdang, Selangor, Malaysia, ${ }^{3}$ Faculty of Food Educational Studies, Universiti Putra Malaysia, \\ 43400 UPM Serdang, Selangor, Malaysia, ${ }^{4}$ Faculty of Hotel and Tourism Management, \\ Universiti Teknologi MARA Puncak Alam, Selangor, Malaysia \\ Email: shahrim@upm.edu.my
}

\begin{abstract}
The aim of this research was to explore the impact of modern technology, especially on convenience food and modern cooking equipment used in the preparation and cooking processes of traditional food in the daily lives of Malay households. A qualitative case study approach was applied in this study. The study also adopted in-depth semi-structured interviews with a total of ten informants comprising seven Malay mothers and three Malay daughters who practice Malay traditional food in their daily lives. The collected data were also supported with the participants' observations. Results of this study revealed that modern technology had greatly influenced the preparation and cooking processes of the Malay traditional food in the following ways: (1) several Malay traditional cooking equipment are no longer suitable for use today, (2) modern technology cannot compete with the taste and aroma of the Malay traditional food that is prepared and cooked traditionally, and (3) modern technology can help sustain the Malay traditional food. These findings demonstrated the impact of modern technology in ensuring the sustainability of the Malay traditional food.
\end{abstract}

Keywords: Malay Traditional Food, Convenience Food, Modern Cooking Equipment, Modernisation of Malay Traditional Food, Sustaining Malay Traditional Food.

\section{Introduction}

The Malay traditional food are reflections of the Malay ethnic that is rich with tradition and culture. It is known for its strong, spicy and aromatic flavours from the use of various herbs and spices (Amira \& Artinah, 2015; Ismail et al., 2015; Sharif et al., 2016), whereby the cooking method is also one of the key elements that signify the uniqueness of Malay traditional food. AGROCERT (the standardisation, inspection and certification authority in Greek agriculture) proposed a comprehensive definition of traditional food, 
encompassing three main criteria. The criteria include: (1) the use of traditional raw resources that have been used in identifiable geographical origins in the past and are still being used today; (2) traditional formulation of ingredients that have been passed down from one generation to another; and lastly (3), traditional type of production and/or processing that has been passed down from generation to generation through oral tradition or other means and is still applied today (Trichopoulou et al., 2006). In relation to this, the Malay traditional food had been prepared and cooked using the original ingredients and the same cooking method as in the past for generations.

On the other hand, modernisation has led to the availability of various convenience foods and modern cooking equipment that can help speed up the cooking process. This is because the Malay traditional food commonly used several cooking methods, such as menumis (onions, garlic, chilli paste, or spices are sautéed before the main ingredients such as vegetables, fish or meat are added to the dish), and menyangai (dry spices, peanut or grated coconut are fried without using oil in a small pan over low heat). Furthermore, other cooking methods include menyalai (meat or fish are smoked or grilled on fire), and melayur (the grilling of banana leaves until it turns dark green to soften them so that they will not break when folded as a food wrap) (Raji et al., 2017). All the aforesaid methods can take a long time to cook due to their elaborate cooking processes. This has altered the lifestyle of many Malaysians today, especially those who prefer a fast and easy lifestyle will choose not to cook the Malay traditional food from scratch and in the worst-case scenario, they might choose not to cook the Malay traditional food altogether. Consequently, the sustainability of the Malay traditional food could adversely be affected by these changes as the practice of Malay traditional food would be neglected and soon disappear.

Nevertheless, past studies had shed light on how contemporary cooking had influenced the sustainability of Malay traditional food (Ismail et al., 2013; 2015). However, these studies focused only on the hospitality industry and little is known about how the preparation and cooking processes of the Malay traditional food have been affected by modern technology. Therefore, this study will explore the impact of modern technology on the process of preparing and cooking the Malay traditional food in the daily lives of the Malay households.

\section{Literature Review}

\section{Characteristics of Malay Traditional Food}

Historically, the Malay traditional food had been strongly influenced by the Arab, European, Portuguese, Dutch and British traders since the $15^{\text {th }}$ century. Moreover, the assimilation and acculturation amongst various ethnicities, such as the Chinese, Indian, Siamese, Javanese, Buginese, and the Minang, have resulted in potpourri formation of Malay food culture tradition (Nur-Syuhada et al., 2015; Sharif et al., 2015). The Malay traditional food is often described with a spicy and aromatic flavour as well as a rich taste in herbs and spices (Nur-Syuhada et al., 2015; Rahman et al., 2018). Varieties of ingredients such as serai (lemongrass), pandan leaves (screwpine), kaffir lime leaves as well as fresh herbs including kemangi (a type of basil), daun kesum (polygonum or laksa leaf), kunyit (turmeric) and bunga kantan (wild ginger buds) are often used in cooking the Malay traditional food. Moreover, traditional spices such as jintan manis (fennel), jintan putih 
(cumin), ketumbar (coriander), buah pelaga (cardamom), and biji sawi (mustard seeds) are also frequently used to enhance the taste of the Malay traditional food (Sharif et al., 2013).

In addition, the Malay traditional food can also be categorised based on the geographical regions of Malaysia. Given the location of the northern states of Malaysia that is closer to the neighbouring country, Thailand, the Malay traditional food in Penang, Perlis and Kedah are known for their strong, fiery-hot spicy and sour flavours (Sharif et al., 2013). Raji et al. (2017) added that tamarind, sour carambola, lime and fresh bird's eye chillies are some of the popular ingredients in Malay traditional food in the northern region, commonly used in the Thai food as well. Similarly, Kelantan and Terengganu, which are located at the east coast of Malaysia, also show distinct Thailand's influence in their traditional Malay food. However, the Kelantanese food is sweeter than the Terengganu food (Nor et al., 2012).

On the other hand, the Malay traditional food in Malaysia's southern and central regions are strongly influenced by the Indonesians. The sour, sweet and spicy flavours reflected the Javanese influence, whereas the extensive use of thick coconut milk and spicy flavours showed the influence of the Minangs. For instance, dishes such as mee rebus jawa, mee bandung, satay and lontong are popular in the areas with Javanese influence, such as Johor and Selangor, while rendang minang and masak cili padi are the Negeri Sembilan signature traditional food (Raji et al., 2017; Sharif et al., 2012).

\section{Malay Traditional Cooking Equipment}

In terms of cooking equipment, dapur kayu or dapur kongkong (wooden stove) was used as the main equipment to cook food in a typical Malay kitchen in the past. It has a rectangular shape and is similar to a desk. It is made from several plywood pieces that serve as walls and foundations. It consists of two parts, which are sabak (furnace) and tungku (riser stone with double horizontal rod iron) (Abdul Wahab et al., 2015). The two furnaces are placed in the middle of the dapur kayu or dapur kongkong, while two long iron bars are placed across the furnaces. Firewood is used as the main fuel, whereas a short bamboo, also known as sentang, is used to blow the bonfire or when the fire is about to go out (Bakhtiar, 2010). However, these traditional cooking equipment are hardly available in today's Malay houses and may only be found in the rural areas or villages (Raji et al., 2017), as more people prefer to use modern cooking equipment like gas stoves and electric stoves.

Besides, kukur kelapa (coconut rasper), lesung batu (pestle and mortar) and batu giling (a hand grinder made of stone) are also some of the essential tools used to prepare food ingredients (Abdul Wahab et al., 2015). Even though these tools are no longer widely used, many people still choose to use lesung batu as it can still be found in the Malay houses presently. The use of lesung batu is claimed to produce a unique flavour that cannot be produced with modern cooking equipment, such as blenders and food processors (Rahman et al., 2018). On the other hand, the use of kukur kelapa has been replaced with electric coconut grater, which can be found in most grocery stores wet markets (Raji et al., 2017). It is more convenient to use an electric coconut grater or buy grated coconut because it can save time and energy rather than sitting on a bench and holding one half of a coconut shell and grating the white coconut flesh against the metal spike in an up-and-down motion. All of these changes indicate that people's lifestyle has gradually changed over time 
due to the waves of modernisation. With the presence of modern cooking equipment, the methods of preparing and cooking the Malay traditional food have also been modified as most of them are no longer prepared and cooked traditionally.

\section{The Modernisation of Malay Traditional Food}

The emergence of convenience food has also made a major impact on Malay traditional food, particularly in terms of food ingredients. Nowadays, the Malay traditional food ingredients, which are available in the market come in many forms. As posited by Sharif et al. (2016), there were three types of Malay traditional food ingredients: liquid, solid (paste), and powder. For instance, instant or pasteurised boxed coconut milk, which falls under the liquid category, is used to replace grated coconut and this eliminates the step of squeezing coconut milk out of grated coconut. The chef can instantly add the coconut milk while cooking using the boxed coconut milk. Besides, food ingredients like chilli paste, chilli powder and turmeric powder are also some of the main and commonly used ingredients in cooking traditional Malay food. Back in the days, chilli and turmeric would be dried in the sun for a few days before they were ground into a powder form. The dried chilli can also be used to make chilli paste, but it should be boiled with hot water before grinding into a chilli paste. Nowadays, these ingredients can easily be found in a processed and convenient form in the market (Figure 1) and most people choose to buy them to save themselves from the tedious processes of preparing and cooking the Malay traditional food.
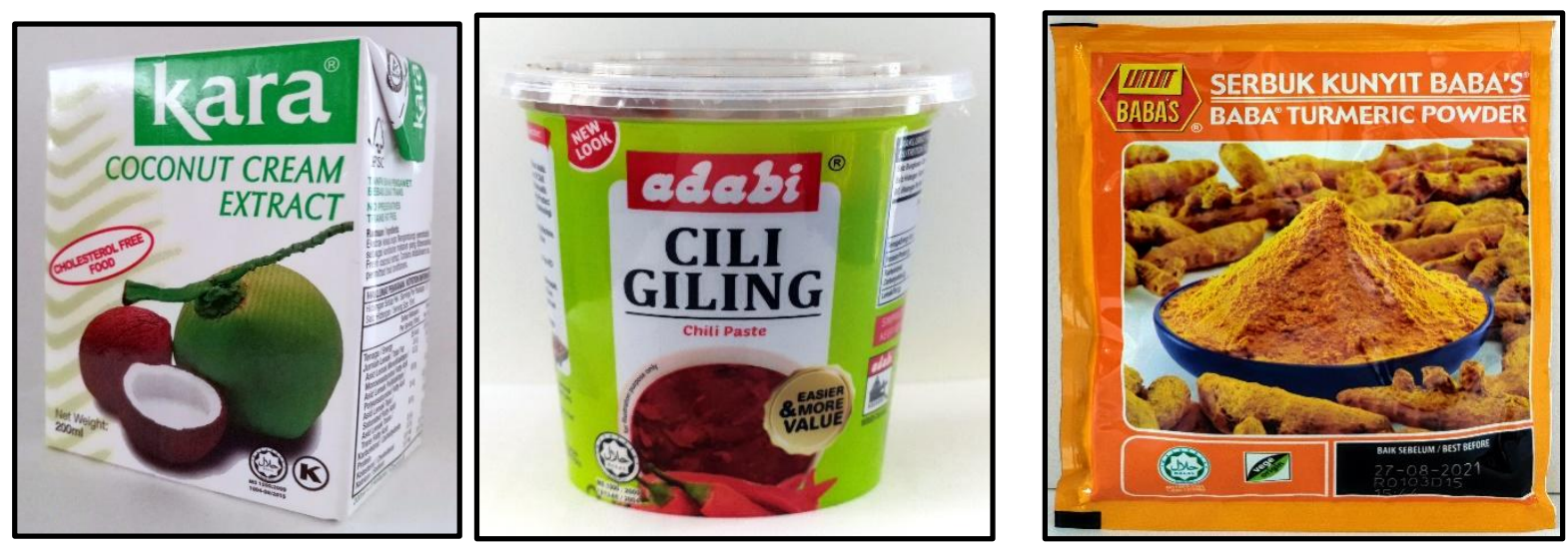

Figure 1. Boxed coconut milk (left), chilli paste (middle) and turmeric powder (right) are some of the convenience food ingredients that are largely available in the market.

Furthermore, there are also varieties of Malay traditional food that have been processed and are ready-to-eat. For example, Figure 2 illustrates two of the most famous Malay traditional foods: nasi lemak and chicken rendang. These products are ready for consumption or it can be heated using microwave or boiling water before consumption. Besides, convenience foods also require some added ingredients whilst cooking to enhance the flavour to make it more delicious (Figure 3). 


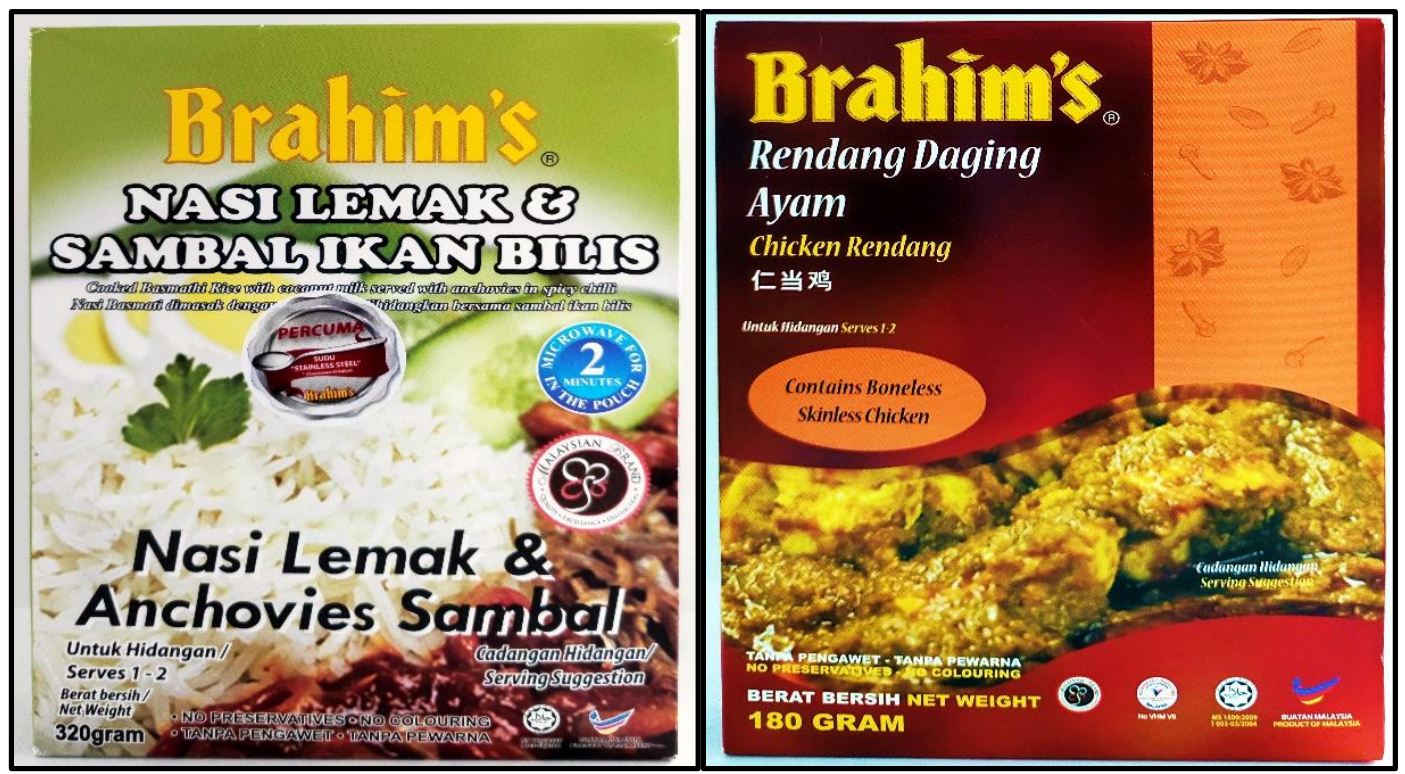

Figure 2. The ready-to-eat nasi lemak and chicken rendang

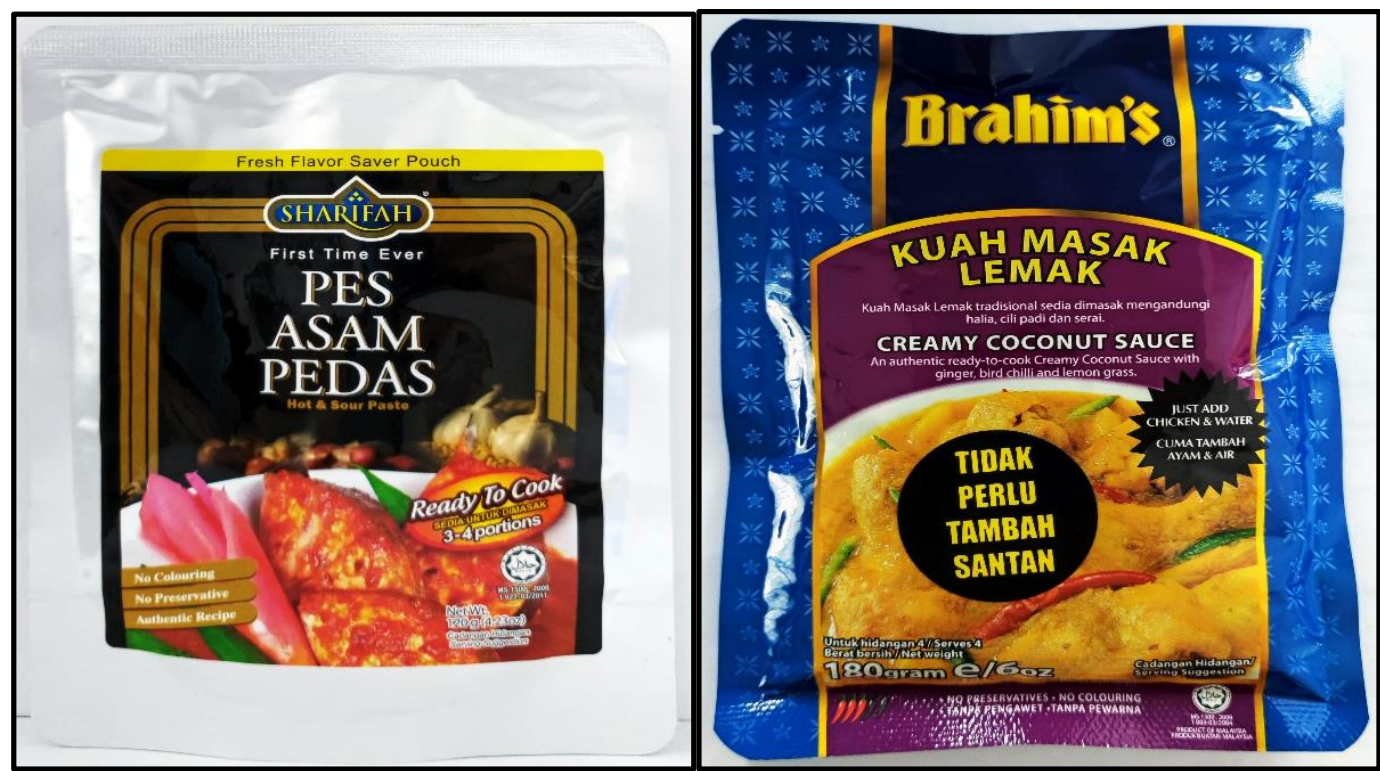

Figure 3. Asam pedas (left) and kuah masak lemak (right) are some of the Malay traditional foods that have been processed into convenience food products. Ingredients such as fish or chicken and vegetables need to be added when cooking to complete the dishes.

In contrast, convenience food is often associated with an unhealthy diet (Daniels \& Glorieux, 2015; Jackson \& Viehoff, 2016) and deskilling of food provisioning due to the lack of cooking ability (Bava et al., 2008; Halkier, 2016; Simmons \& Chapman, 2012). According to Bava et al. (2008), food provisioning was a continuous cyclic process of activities without a fixed starting and ending point. These activities included going to the supermarket, purchasing grocery items, preparing the meal components, cooking the meal components, consuming meals, cleaning up, freezing and storing leftovers. Nonetheless, people choose to consume convenience food to make their lives more convenient and easier. As explained by Buckley et al. (2007) and Osman et al. (2014), convenience food could save time, physical energy, and mental effort related to food preparation, consumption, and clean-up. This was also supported by Sharif et al. (2016) who noted that convenience food could help 
reduce the preparation and time spent in the kitchen, and thus, eliminated some tedious preparation methods, such as cleaning and grinding the food ingredients.

\section{Methodology}

Qualitative research was applied in this study, as Merriam and Tisdell (2015) explained the purpose of conducting qualitative research was to help the researcher to understand the phenomenon of interest from the informant's perspective and not from the researcher's perspectives. Thus, a qualitative approach is appropriate to be used in this study because it focuses on exploratory and in-depth understanding regarding the impact of modern technology on the process of preparing and cooking the Malay traditional food in the daily lives of the Malay households. Therefore, ten informants comprising seven Malay mothers and three Malay daughters who practice Malay traditional food in their daily lives were selected using purposive and snowball sampling techniques. The informants were categorised as Mother 1- 7 and Daughter 1 - 3 for this study. The informants were contacted beforehand through the telephone with a brief explanation about the purpose of the study.

Then, the appointment was made according to the informants' time, availability and their preferred location for the interview to be done. The researcher conducted face-toface interviews, whereby each interview session lasted approximately an hour to one and a half hours. In-depth semi-structured interviews were also used in this study as this would give the researcher a chance to probe for details. The entire interviews were recorded using a voice recorder with consent from the informants. Next, the researcher transcribed verbatim transcripts manually and constant comparative methods were used to analyse the data. This technique was used to establish codes and categories for the development of key themes to answer the study's research questions. Moreover, the participants' observations were also used to strengthen the finding of this study, as Creswell (2003) stated that observation could be an effective method to complement other methods. The NVivo software facilitated the analysis of these collected data and the identity of informants would remain anonymous to protect their confidentiality.

\section{Result and Discussions}

Data were analysed to identify the main themes highlighting the informants' perspectives on the impact of modern technology on the Malay traditional food preparation and cooking processes in their daily lives. The results identified a total of three themes, which included (1) several Malay traditional cooking equipment are no longer suitable for use today, (2) modern technology cannot compete with the taste and aroma of the Malay traditional food that are prepared and cooked traditionally, and (3) modern technology can help sustain the Malay traditional food.

\section{Several Malay traditional cooking equipment are no longer suitable for use today}

In the past, the Malay traditional food was cooked using traditional equipment, for example, dapur kayu or dapur kongkong. However, this traditional cooking equipment is no longer suitable for use currently. This is because the present-day houses and the residential areas do not support this traditional cooking equipment as it can be seen as open burning. Daughter 2 said,

"...as for me, I actually prefer the traditional method of cooking, because the food is tastier and more authentic. However, due to lack of materials, space, and furthermore, 
our residential area is inappropriate for open burning. Therefore, I have to conform to the current modernisation. ..."

Mother 5 was another informant, who said that it was inappropriate to cook Malay traditional food using the traditional method. She said, "...it is difficult because you have to do open burning. It does not seem right. But sometimes, we have to tolerate and modify the cooking technique. ..." These findings were supported by another informant who stated that there was some Malay traditional food that could still use the traditional methods. Still, it could be difficult to cook certain Malay traditional food that used traditional equipment such as the charcoal kitchen. She also added that she took the approach of using modern cooking equipment to cook Malay traditional food. Mother 3 said,

"...there are things that we can do traditionally. For example, if we would like to cook rendang, we can still follow the traditional method. But there are things that we cannot do traditionally, for example, grilling to make ikan percik. Where can I get the charcoal kitchen and the charcoal? So, the taste will not be the same, but I still grill it in the oven. Moreover, if I want to make kuih bakar, I have to find coconut coir. So, I cannot do it (using the traditional methods of cooking)."

These findings were consistent with data found in the participants' observations, whereby both Daughter 2 and Mother 5 were using gas stoves for cooking. As posited by Abdul Wahab et al. (2015), the kitchen is one of the main features in the traditional Malay houses, whereby dapur kayu or dapur kongkong was built by the homeowner or sometimes by the carpenter, depending on the homeowner's request, during the house construction. However, the traditional Malay houses had undergone many changes since World War II. The structure and design of traditional Malay houses were replaced with modern housing (Kamal, Abdul Wahab and Che Ahmad, 2004). Unlike traditional Malay houses, modern housings are designed to have modern cooking space and this means that the cooking equipment used should also be modern and up-to-date. This makes it difficult to cook Malay traditional food using traditional cooking equipment. Thus, the traditional cooking methods are modified in accordance with the modern cooking equipment used to ensure that the informants can still cook the Malay traditional food.

\section{Modern technology cannot compete with the taste and aroma of Malay traditional food that are prepared and cooked traditionally}

Based on the in-depth semi-structured interviews, it was found that the Malay traditional food that are cooked using contemporary methods do not taste and smell the same as when they are cooked traditionally. This is due to the way they are prepared has been modified. Traditionally, the spices will go through a cooking process called sangai, whereby the dried spices are fried without using any oil before being pounded into powdered form. Nowadays, these powdered spices can easily be found in the market. Mother 2 stated that,

"...however, the taste is not the same. Because spices such as coriander, fennel and white cumin, need to be sangai to get a fragrant smell, especially if they are traditionally prepared. Then the oil from the seeds will surface, which is the aroma that we smell. Thereafter, we grind the spices. Today, the spices are readily available in powdered form. You just have to mix them. Sometimes we 
buy the spices at the store, which might have been mixed with a kind of preservative so that the powder does not clump. ..."

Another informant mentioned that she pounded the food ingredients to cook gulai because the taste will not be good if a food blender is used to grind the ingredients. Gulai and asam pedas are famous Malay traditional food versions of fish soup or stew. Although there are various ways to cook these two dishes, gulai is known for its thick coconut milk and spicy taste, whereas asam pedas is known for its spicy and sour taste. Mother 6 said,

"...I will pound the bird's eye chillies if I want to make gulai. I do not use the blender for it will not be delicious. But I use the blender if it is red or dried pepper. If I want to cook asam pedas, then I use the blender. However, if you want to cook gulai, you just need to pound the bird's eye chillies a little bit. If you use the blender, the taste will not be delicious. ..."

Interestingly, these findings were synchronised with Mother 4 and Mother 5, whereby both of them admitted they used a blender to make chilli paste. Mother 4 said,

"...I always have chilli paste that I make at home. When you blend the chillies, there are several steps to note. Firstly, the chillies are cut into pieces and then boiled. You do not want to have a lot of chilli seeds. Thereafter, the chillies are blended with onions and garlic, and then the chilli paste are kept in the fridge."

Mother 5 further emphasised that in contrast to the Malay traditional cooking equipment, such as lesung batu that could produce natural unique flavours from the pounded food ingredients, water should be added into the blender to ensure that the ingredients are well-mixed to make the food taste different. She said,

"...let's say when we cook rendang or sambal tumis, when we pound or blend the onions, in terms of taste and aroma, we will know that it is not good enough. The taste is not what it used to be. I guess when we pound the onions, it will not be finely crushed. Furthermore, we do not have to add water when we pound the onions. However, if we blend the ingredients, it will be finely chopped. Then we will add water to ensure the ingredients are well-blended. Therefore, it will produce a very different taste. ..."

On the other hand, data analysis from in-depth semi-structured interviews and the participants' observations also found that ready-made kerisik were bought instead of cooked from scratch even though the taste and aroma were not the same as traditionally made. Mother 4 said, "... for example, when we cook rendang, the kerisik that we used was traditionally made. Although the kerisik are available in the market, they are not as greasy and fragrant as traditionally made. ..." In addition, Daughter 3 stated that her mother bought kerisik from a trusted seller. She said, "...my mom bought the kerisik from the villagers and not from the supermarket..." These findings were consistent with data found in the participants' observations, whereby Mother 5 bought kerisik from the wet market.

As mentioned by Sharif et al. (2016), kerisik (pounded toasted grated coconut paste) was one of the main ingredients in cooking rendang (spicy meat dish braised in coconut milk and ground spice paste). The grated coconut should be pan-toasted over low heat until 
the general distribution of the coconut is golden brown. Then the toasted coconut needs to be pounded into an oily paste. The long and tedious process of making kerisik makes people choose to buy them from the market at times. This indicates that they still choose to use modern technology, such as blender and ready-made kerisik in their cooking, even if this means that they have to compromise with the taste and aroma of the Malay traditional food that will be different in taste if they are prepared and cooked traditionally. This also showed that although they did not buy the processed chilli paste, they could still make it themselves and keep it in the fridge for prolonged use. This is one of the contemporary and innovative ways to facilitate the Malay traditional food preparation and cooking processes.

\section{Modern technology can help sustain the Malay traditional food}

Data analysis revealed that convenience food was a good indicator in sustaining the Malay traditional food. This was because, without the use of convenience food, the Malay traditional food might be overlooked due to its complicated preparation and cooking processes. Mother 4 said,

"...but now, with the technological advancements in the food industry, there are many things that we can get in the form of pre-prepared food. For example, paste such as rendang paste, curry paste, and various other pastes are available in the market. For $m e$, that is a good indication. The reason is, if we do not have such a guide as a helpful indicator, I am afraid these traditional foods will be forgotten, because the preparation process (Malay traditional food) is difficult. ..."

Moreover, this finding was supported by Mother 2 who highlighted the use of convenience food is better suited to today's contemporary lifestyle, which is more concerned about spending quality time with family than cooking in the kitchen. Besides, convenience food is seen as one of the ways to simplify the preparation and cooking processes of Malay traditional food that have elaborate and tedious steps. Above all, this will help the sustainability of Malay traditional food, as the future generation can still recognise and eat the Malay traditional food. She said,

"...most importantly so that the future generations can still recognise the Malay traditional food. I think innovation will cause... our modern society... to always prioritise time, for example, insufficient time or quality time to spend with the family. These instant pastes will play a bigger role in the preparation of traditional food. It does not matter if the taste may change. Not like when... of course, as I share, if we prepare the food from scratch, the taste will be different from these pastes. However, these pastes are still useful rather than leave out (not cooking Malay traditional food) entirely. Meaning to say, if you want to make Bandung noodles, take a paste and just pour some water. Even with Laksa Sarawak, just use this (paste). Nevertheless, we are still feeding our children with the Malay traditional food. ..."

Mother 3 further emphasised these findings and stated that although the Malay traditional food was prepared and cooked using the convenience food and modern cooking equipment, which were considered unauthentic, they were still considered traditional food. However, the taste of the food should be similar to the original taste of the Malay traditional food. She stated that, 
"...the food is still considered as traditional food, although the way they are cooked is not traditional. However, if we say that is bad, then the traditional food will slowly disappear and people would not even know about it. This is due to the children's love for fast food... you will lose it. Well, we have to ensure that even if it is pre-prepared or processed food, the taste should be similar to the original (Malay traditional food)."

Mohammad and Chan (2011) noted that authentic Malay traditional food reflected the genuine taste of the Malay ethnic culture. Therefore, the food should be cooked using the traditional cooking method to achieve the genuine authentic taste of the Malay traditional food. However, the processes of preparing and cooking Malay traditional food have been modified with the advancement of modern technology. As a result, these Malay traditional foods cannot be claimed as authentic, but they are still called Malay traditional food. Previous studies have shown that the younger generation in Malaysia had gradually ignored the practice of Malay traditional food (Ling \& Onn, 2016; Nor et al., 2012) and one of the factors that contributed to this problem was the complicated steps involved in preparing and cooking the Malay traditional food (Sharif et al., 2013). Hence, the usage of convenience food and modern cooking equipment to cook Malay traditional food can be seen as an innovative effort to maintain our precious traditional food.

\section{Conclusion}

In this ever-changing world, modernisation inevitably affects all aspects of our lives, which in this study particularly, it affects the preparation and cooking processes of the Malay traditional food. The impact of modern technology could be seen through the emergence of convenience food and modern cooking equipment where in the past, these technologies were unimaginable. Hence, this study helped to expand the knowledge on Malay traditional food by giving a better insight into how the Malay traditional food preparation and cooking processes are affected by modern technology. The findings from this study suggested that people still choose to cook and eat Malay traditional food even though they have modified the preparation and cooking processes to suit their lifestyles. Not only that, they also have a positive view about the impact of modernisation on their lifestyles. They take their initiatives to prepare and cook the Malay traditional food that will give them a similar taste to traditionally prepared and cooked food.

From a practical perspective, the outcome of this study could help broaden the views of stakeholders, particularly those involved in the hospitality industry, on the use of modern technology to sustain the Malay traditional food. In addition, findings from this study might also contribute theoretically and conceptually in which quantitative researchers could include modern technology as one of the factors that could assist the sustainability of the Malay traditional food in their studies. Nevertheless, the scope of this study is limited to the Malay society as the researcher had selected Malay women as one of the informant's criteria. This study is also limited to the women's perspectives regarding the impact of modern technology on the Malay traditional food preparation and cooking processes. Therefore, future studies could explore perspectives from other ethnic groups in Malaysia, such as the Chinese and Indians, as well as to get comprehensive research on the Malay traditional food. 


\section{Corresponding Author}

Shahrim Ab Karim. Faculty of Food Science and Technology, Universiti Putra Malaysia, 43400

UPM Serdang, Selangor, Malaysia.

Email: shahrim@upm.edu.my

\section{References}

Abdul Wahab, M. H., Awang, M., Awang Lah, N. A., \& Abd Hamid, A. B. (2015). Malay traditional kitchen furniture: A form and function. Proceedings of the Colloquium on Administrative Science and Technology. https://doi.org/10.1007/978-981-4585-45-3

Amira, S. N., \& Artinah, Z. (2015). Uncertainty avoidances among international students towards Malay food acceptance. Journal of Education and Vocational Research, 6(1), 79-82.

Bakhtiar, H. A. (2010). Peralatan Tradisional Melayu. Jurnal Warisan Indera Kayangan, Bahagian 1, 27-33.

Bava, C. M., Jaeger, S. R., and Park, J. (2008). Constraints upon food provisioning practices in "busy" women's lives: Trade-offs which demand convenience. Appetite, 50(2-3), 486498. https://doi.org/10.1016/j.appet.2007.10.005

Buckley, M., Cowan, C., \& McCarthy, M. (2007). The convenience food market in great Britain: convenience food lifestyle (CFL) segments. Appetite, 49(3), 600-617.

Creswell, J. W. (2003). Research design: qualitative, quantitative and mixed method approaches (2nd ed.). Thousand Oaks: Sage Publications.

Daniels, S., \& Glorieux, I. (2015). Convenience, food and family lives. A socio-typological study of household food expenditures in 21st-century Belgium. Appetite, 94, 54-61.

Halkier, B. (2016). Normalising convenience food? Food, Culture \& Society, 1-19. doi:http://dx.doi.org/10.1080/15528014.2016.1243768

Ismail, N. A., Ab. Karim, M. S., Othman, M., \& Abd. Halim, N. (2013). The values of the traditional culinary practices towards the modernization as perceived by the Malay chefs in Klang valley. International Food Research Journal, 20(5), 2857-2864. https://doi.org/10.5901/mjss.2013.v4n11p13

Ismail, N. A., Ismail, N. A., Othman, M., \& Abdul Karim, M. S. (2015). The man behind the wok: The hotels' Malay chefs work recipes. Jurnal Teknologi, 10(October), 11-14.

Ismail, N. A., Fazamimah, N. M., Othman, M. A., \& Ab Karim, M. (2015). Preserving authenticity of the Malay traditional food in hotel industry: Is it possible with modern cooking technology? Advances in Environmental Biology, 160-163.

Jackson, P., \& Viehoff, V. (2016). Reframing Convenience Food. Appetite, 98, 1-11. https://doi.org/10.1016/j.appet.2015.11.032

Kamal, K. S., Abdul Wahab, L., \& Che Ahmad, A. (2004). Climatic design of the traditional Malay house to meet the requirements of modern living. The 38th International Conference of Architectural Science Association ANZAScA "Contexts of architecture", (pp. 175-179). Tasmania.

Ling, T. A., \& Onn, Y. T. (2016). Motives for millennials' choice on traditional food and their level of consumption: A cross-cultural comparison. Food \& Society 2016 International Conference.

Merriam, S. B., \& Tisdell, E. J. (2015). Qualitative Research: A Guide to Design and Implementation (4th ed.). John Wiley \& Sons. 
Mohammad, T., \& Chan, J. K. L. (2011). Authenticity representation of Malay Kelantan ethnic cuisine. The 2nd International Research Symposium in Service Management, July, 458466.

Nor, N. M., Sharif, M. S. M., Zahari, M. S. M., Salleh, H. M., Isha, N., and Muhammad, R. (2012). The Transmission modes of Malay traditional food knowledge within generations. Procedia - Social and Behavioral Sciences, 50(July), 79-88. https://doi.org/10.1016/j.sbspro.2012.08.017

Nur-Syuhada, J., Fadzilah, M., Khairunnisa, M., \& Rosmaliza, M. (2015). The influence of Malay food characteristics on customer purchase intention. Theory and Practice in Hospitality and Tourism Research - Proceedings of the 2nd International Hospitality and Tourism Conference 2014, 459-463.

Osman, I., Osman, S., Mokhtar, I., Setapa, F., Shukor, S. A. M., \& Temyati, Z. (2014). Family food consumption: Desire towards convenient food products. Procedia - Social and Behavioral Sciences, 121(September 2012), 223-231. https://doi.org/10.1016/j.sbspro.2014.01.1123

Rahman, S. A. G., Ab Karim, S., Ishak, F. C., \& Arshad, M. (2018). Understanding the young generations' preference towards Malay traditional food in Malaysia. Journal of, 42-57.

Raji, M. A., Ab Karim, S., Ishak, F. C., \& Arshad, M. (2017). Past and present practices of the Malay food heritage and culture in Malaysia. Journal of Ethnic Foods, 221-231.

Sharif, M. S. M., Nor, N. M., Abdul Rahman, A. E., \& Abdullah, K. M. (2016). The modernization of Malay food ingredients: A qualitative investigation. Environment Behaviour Proceedings Journal, 1(3), 9-10.

Sharif, M. S. M., Zahari, M. S. M., Ishak, N., Muhammad, R., Noor, A. M., \& Salleh, H. M. (2012). Traditional food knowledge (TFK) of Malay festive foods. Current Issues in Hospitality and Tourism Research and Innovations, January, 365-369. http://www.scopus.com/inward/record.url?eid=2-s2.084866887495\&partnerID=tZOtx3y1

Sharif, M. S. M., Zahari, M. S. M., Nor, N. M., \& Muhammad, R. (2013). Factors that restrict young generation to practice Malay traditional festive foods. Procedia - Social and Behavioral Sciences, 101, 239-247. https://doi.org/10.1016/j.sbspro.2013.07.197

Sharif, M. S. M., Zahari, M. S. M., Nor, N. M., \& Muhammad, R. (2016). Restriction on Malay traditional food practices. Asian Journal of Quality of Life, 1(1), 12. https://doi.org/10.21834/ajqol.v1i1.11

Sharif, M. S. M., Zahari, M. S. M., Muhammad, R., \& Nor, N. M. (2015). Traditional hari raya food: An insight from three Malay women generations. Theory and Practice in Hospitality and Tourism Research, 505-509.

Trichopoulou, A., Vasilopoulou, E., Georga, K., Soukara, S., \& Dilis, V. (2006). Traditional foods: Why and how to sustain them. Trends in Food Science and Technology, 17(9), 498-504. https://doi.org/10.1016/j.tifs.2006.03.005 